\title{
MENINGKATKAN KEMAMPUAN BERCERITA ANAK MELALUI MEDIA GAMBAR DI LINGKUNGAN RT 017, RW 08, JATINEGARA, JAKARTA TIMUR
}

\author{
Nur Indah Sari, Sri Mulyani, Eka Septiani
}

Program Studi Pendidikan Matematika, Fakultas Matematika dan IPA, Universitas Indraprasta PGRI

\begin{abstract}
Abstrak
Penggunaan media gambar sebagai sumber belajar dapat menarik minat dan semangat anak dalam belajar sehingga anak tidak merasa bosan atau mengalami kejenuhan. Media gambar diharapkan dapat membangkitkan rasa ingin tahu anak akan peristiwa atau cerita, membantu anak untuk mengembangkan imajinasi, mengkaitkan tema-tema dalam gambar dengan pengalaman hidup sehari-hari, lebih berani mengemukakan ide-idenya sehingga anak lebih lancar dalam bercerita. Pada program penyuluhan dan pengabdian masyarakat ini, akan berfokus pada anak. Orangtua menjadi pendamping karena orang tua menjadi pendidikan awal bagi anak-anak dalam kehidupan bersosial. Hasil yang dicapai dalam program pengabdian pada masyarakat ini menunujukkan bahwa (1) penggunaan metode bercerita sangat efektif dalam meningkatkan motivasi kemampuan berbahasa, (2) penggunaan media gambar sangat mendukung kegiatan pembelajaran, (3) memotivasi anak untuk belajar berkomunikasi, bercerita dan bersosialisasi, (4) Kemampuan berbahasa anak dapat berkembang dengan baik, anak mampu menceritakan tokoh-tokoh dalam gambar.
\end{abstract}

Kata Kunci : Kemampuan Bercerita, Media Gambar.

\begin{abstract}
The use of media images as a learning resource to attract interest and spirit of the child in learning so that children do not feel bored or experience burnout. Media images are expected to arouse the curiosity of children going event or story. helps children to develop imagination, linking the themes in the pictures with the experience of everyday life, more willing to put forward its ideas so that children are more fluent in storytelling. In the program of counseling and community service, will focus on children. Parents become a companion for the elderly into early education for children in bersosial life. The results achieved in the service programs of the society is menunujukkan that (1) the use of the storytelling method is very effective in increasing the motivation of language skills, (2) use of media image is very supportive of learning activities, (3) motivate children to learn to communicate, talk and socialize, (4) the ability of children to develop properly, children are able to tell the characters in the image.
\end{abstract}

Keywords : Ability Storytelling, Media Image.

Correspondence author: Nur Indah Sari, indahleychee@gmail.com, Jakarta, Indonesia

This work is licensed under a $C C-B Y-N C$ 


\section{PENDAHULUAN}

Bahasa merupakan aspek yang sangat penting dalam kehidupan sehari-hari. Pengertian Bahasa menurut Keraf (dalam Suyanto, 2011: 15) menyatakan dua pengertian. Pengertian pertama menyatakan bahwa bahasa sebagai alat komunikasi antar anggota masyarakat berupa simbol bunyi yang dihasilkan oleh alat ucap manusia. Kedua, bahasa adalah sistem komunikasi yang menggunakan simbol-simbol vokal (bunyi ujaran) yang bersifat arbitrer. Setiap orang memiliki bahasa, akan tetapi tidak semua orang memiliki keterampilan berbahasa dengan baik. Keterampilan berbahasa dapat kita asah. Keterampilan berbahasa memiliki empat komponen, yaitu menyimak, berbicara, membaca, dan menulis. Keempat komponen tersebut erat hubungannya satu dengan yang lain. Keempat keterampilan berbahasa itu diperoleh secara berurutan. Mula-mula pada masa kecil belajar menyimak, belajar berbicara, membaca, dan urutan terakhir, yaitu menulis. Kemampuan berbicara merupakan kemampuan untuk menuangkan perasaan, ide-ide atau gagasan melalui bahasa lisan. Kemampuan berbicara khususnya bercerita perlu dibangun sejak usia dini. Oleh karena itu, sebagai orang tua diharuskan untuk slalu mengajarkan bercerita pada putra-putrinya dari usia balita. Dengan mengajarkan berbagai cerita pada anak, itu berarti orang tua telah membangun pada pendidikan anak agar anak mengenal atau mengetahui karakter berbagai cerita dan penokohan dalam cerita. Misal: cerita Malin Kundang. Walaupun cerita tersebut sudah berabad-abad lamanya, cerita itu masih bisa diceritakan pada anak-anak sampai saat ini, apalagi dalam bercerita disertai dengan media gambar itu sungguh menarik perhatian.

Demi mengembangkan keterampilan berbahasa dan kelancaran kegiatan belajar mengajar, dibutuhkan sebuah media agar dapat berjalan efektif dan lancar. Media pembelajaran sangat penting agar proses belajar mengajar bisa tersampaikan dengan baik. Kata media berasal dari bahasa Latin dan merupakan bentuk jamak dari kata medium, yang artinya perantara atau pengantar. Pengertian media pembelajaran menurut Arsyad (2011: 4) adalah alat bantu pada proses belajar baik di dalam maupun di luar kelas, lebih lanjut media pembelajaran adalah komponen sumber belajar atau wahana fisik yang mengandung materi instruksional di lingkungan siswa yang dapat merangsang siswa untuk belajar. Media belajar yang dianggap cocok dan tidak harus menggunakan biaya mahal, serta memanfaatkan benda-benda di sekitar lingkungan kita, itu juga menarik, sedangkan sumber belajar merupakan segala sesuatu yang diperlukan dalam kegiatan pembelajaran, yang dapat berupa buku teks, media cetak, media elektronik, narasumber, lingkungan alam sekitar, dsb. (Suyanto, 2008: 39).

Media pembelajaran banyak jenis dan macamnya. Pengelompokan media pembelajaran di antaranya: Media Visual, Media Audio, Media Audio Visual, Multimedia, dan Media Realita. Media visual, yaitu media yang hanya dapat dilihat, seperti: foto, gambar, poster, kartun, dan grafik. Media audio, yaitu media yang hanya dapat didengar saja, seperti: kaset audio, mp3, dan radio. Media audio visual, yaitu media yang dapat didengar sekaligus dilihat, seperti: film bersuara, video, televisi, dan sound slide. Multimedia, yaitu media yang dapat menyajikan unsur media secara lengkap, seperti: animasi. Media realita, yaitu media nyata yang ada di lingkungan alam, baik digunakan dalam keadaan hidup maupun sudah diawetkan, seperti: binatang, specimen, herbarium, dll. Media pembelajaran yang digunakan dalam kegiatan ini adalah media gambar. Menurut Sudjana dan Rivai (2009: 56) media gambar terbagi menjadi dua, yaitu 1) media gambar tunggal dan 2) media gambar berseri. Media gambar tunggal adalah media yang memiliki kesatuan informasi yang dituangkan dalam satu lembar, sedangkan 
media gambar berseri merupakan media yang memiliki informasi yang dituangkan dalam beberapa tahapan yang dibuat perlembar, sehingga menjadi informasi yang utuh. Kelebihan media gambar berseri menurut Subana (2011: 324-325), yaitu gambar mudah diperoleh pada buku, majalah, koran, album foto, dsb. dan gambar dapat diterjemahkan dalam ide-ide abstrak dalam bentuk yang lebih nyata dan juga mudah dipakai karena tidak membutuhkan peralatan, serta mudah digunakan dalam berbagai hal dari berbagai sudut pandang keilmuan.

Dari sudut pandang bahasa, gambar termasuk ilmu seni sastra. Gambar dikatakan ilmu seni, karena gambar mampu menumbuhkan imajinasi orang. Dengan melihat gambar, anak-anak atau orang dapat mengembangkan cerita. Bercerita merupakan sarana yang sangat penting dalam kehidupan anak, yaitu sebagai alat komunikasi, alat ekpresi, menyatakan atau menyampaikan pikiran, gagasan dan perasaan kepada orang lain. Menurut Bachri (dalam Ningsih, 2014: 246) bercerita adalah menuturkan suatu kejadian yang mengisahkan tentang perbuatan yang dilakukan secara lisan kepada orang lain, untuk membagikan suatu pengalaman dan pengetahuan, sedangkan Andayani (2015: 25) mengemukakan bercerita merupakan salah satu kompetensi berbicara yang harus dicapai dalam kegiatan pembelajaran siswa sekolah dasar, (Marlina \& Hamdu, 2018). Untuk dapat bercerita dengan baik dan lancar, diperlukan keterampilan khusus, yaitu ingatan yang baik, latihan secara terus-menerus, agar siswa mampu mengembangkan semua imajinasinya (Musfiroh, 2005: 14).

Dengan demikian, bercerita berkaitan erat dengan disiplin ilmu bahasa. Pendidikan bahasa merupakan salah satu aspek proses pembelajaran dasar yang perlu dikembangkan sejak dini. Dalam proses pendidikan pengembangan kemampuan berbahasa merupakan hal dasar yang perlu mendapat perhatian serius, kemampuan berbahasa merupakan modalitas utama bagi siswa untuk mengikuti proses pembelajaran dalam setiap jenjang pendidikan, tidak terkecuali pada jenjang pra sekolah dan sekolah dasar. Oleh karena itu, pembelajaran bahasa perlu ditanamkan sejak dini pada proses pendidikan di taman kanakkanak dan sekolah dasar. Salah satu indikator perkembangan bahasa pada anak-anak usia dini adalah kemampuan bercerita (Moeslichatoen, 2004:10).

Berdasar pada hasil observasi, anak-anakdi RT 17, RW 08, Cipinang Cempedak, Jatinegara, Jakarta Timurkemampuan bercerita melalui gambar masih rendah. Oleh karena itu, tim tergugah untuk melakukan pengabdian kepada masyarakat yang sasarannya anak-anak sekolah dasar. Rendahnya anak-anak dalam bercerita diduga karena para orang tua tidak mengajarkan bercerita pada mereka. Setelah anak-anak mendapatkan penyuluhan tentang meningkatkan kemampuan berceritamelalui gambar, anak-anak mampu mengembangkan idea atau gagasan bercerita dengan baik dan lebih kreatif.

Jadi, bersumber pada uraian di atas, tim Abdimas melakukan pengabdian kepada masyarakat dengan tema" Meningkatkan Kemampuan Bercerita pada Anak melalui Media Gambar di Lingkungan RT 17, RW 08, Jatinegara, Jakarta Timur".

\section{METODE PELAKSANAAN}

Metode pelaksanaan kegiatan menjelaskan tahapan atau langkah-langkah dalam melaksanakan solusi yang ditawarkan untuk mengatasi permasalahan. Berdasarkan permasalahan yang dihadapi mitra maka salah satu solusi yang dapat dilakukan adalah anak sekolah dasar agar gemar bercerita menggunakan media gambar dan dapat 
memanfaatkan benda-benda di sekitar lingkungan tempat tinggal sebagai media untuk berekspresi.Seluruh kegiatan direncanakan dan dilaksanakan dalam waktu empat bulan, yang meliputi beberapa tahapan: persiapan kelengkapan kegiatan,dalam tahapan ini ada beberapa kegiatan yang dilakukan, di antaranya: pemilihan mitra, metode yang digunakan untuk pengabdian, menentukan waktu, mempersiapkan alat-alat dan media yang digunakan, dan merencanakan cara penyajian dan alur kegiatan.

Pemilihan mitra Abdimas bersumber dari pengamatan yang dilakukan selama satu bulan yang dimulai dari bulan Februari sampai awal Maret 2019. Dengan melihat kemampuan anak-anak sekolah dasar di lingkungan RT17, RW 08, Jatinegara belum mampu bercerita dengan baik, tim segera mengadakan rapat untuk membahas masalah yang dihadapi oleh mereka dan perlu memberikan penyuluhan. Dalam melakukan Abdimas, tim menggunakan metode tutorial dan praktik. Dengan penggunaan dua metode ini diharapkan penyuluhan dapat terlaksana dengan baik dan efektif. Terlebih dahulu dimulai dengan memberikan form daftar hadir yang diisi oleh anak-anak. Kemudian tim memberikan penjelasan terkait dengan teori-teori tentang bercerita dan pentingnya gambar dijadikan media untuk meningkatkan kemampuan bercerita.

Penentuan waktu Abdimas, didiskusikan dengan ketua RT 17, RW 08, Jatinegara, Jakarta Timur. Setelah dilakukan kesepakatan, akhirnya antara tim dengan mitra menentukan waktu Abdimas selama empat bulan dari Maret hingga Juni 2019. Kemudian tim, menyiapkan alat-alat yang digunakan untuk menunjang Abdimas, yaitu proyektor, papan tulis, dan alat tulis. Alat-lat tersebut digunakan sebagai media untuk menyampaikan materi tentang teknik bercerita berdasarkan gambar. Dalam pelaksanaanya, tim membawa infokus karena di wilayah itu tidak ada, sementara spidol sebagai alat untuk menulis di papan tulis. Selain itu, tim juga menyiapkan materi dalam bentuk power point.

Untuk terlaksanakan kegiatan pengabdian, tim membuat alur penyajian, yaitu 1) prapelaksana, 2) pelaksanaan, 3) evaluasi, dan 4) pelaporan. Prapelaksanaan: pertamatama tim melakukan pertemuan dengan ketua RT untuk menanyakan permasalahan yang terjadi di wilayahnya. Kedua mengadakan pengamatan terhadap sasaran mitra. Ketiga menyiapkan rancangan susunan acara dan menyiapkan perlengkapan yang dibutuhkan untuk melalukan pengabdian. Pelaksanaan Abdimas dilaksanakan setelah semua musyawarah disepakati antara ketua RT dan tim Abdimas. Pertemuan dibuat menjadi tiga pertemuan, yaitu pertemuan pertama menjelaskan materi, pertemuan kedua menugasi anak-anak praktik mengambar lalu menceritakan. Dan pertemuan ketiga mengevaluasi perkembangan anak membuat cerita berdasarkan gambar.

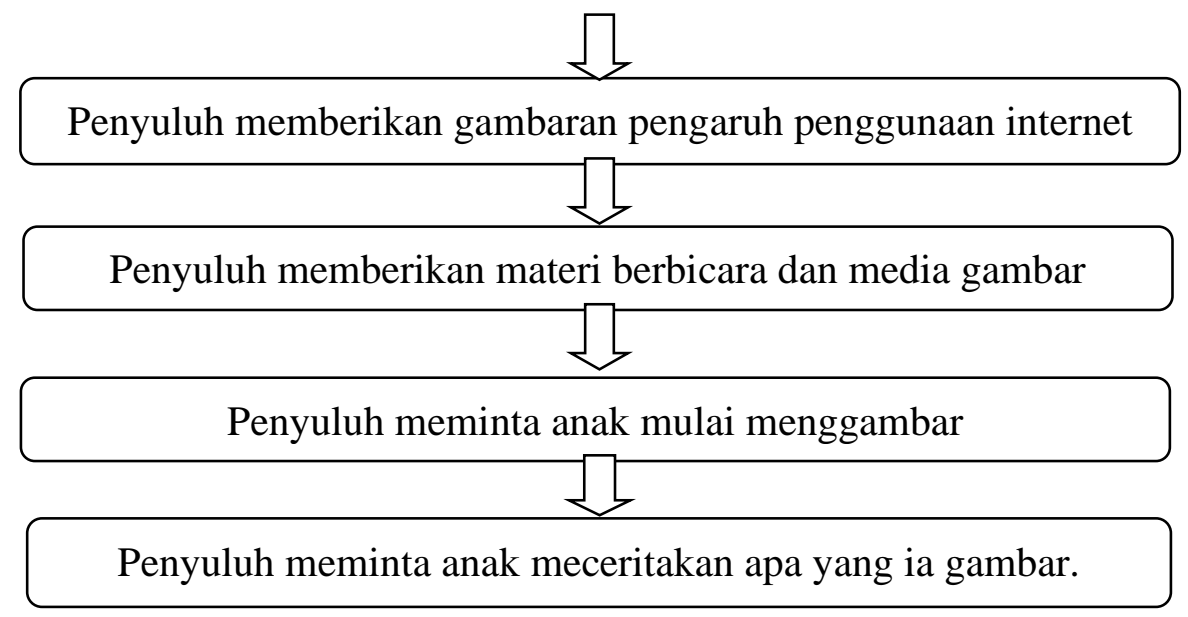


Evaluasi pelaksanaan Abdimas bertujuan untuk melihat perkembangan program yang dilaksanakan. Lagkah yang dilakukan, yaitu mengumpulkan hasil yang diperoleh dari anak-anak tersebut setelah mereka mengambar lalu bercerita. Selain itu, adanya evaluasi dilakukan untuk mengetahui kedalaman yang ada dan mencari penangganannya, sehingga pelaksanaan Abdimas benar-benar berhasil secara efektif dan untuk melakukan pengabdian dengan tema yang berbeda. Setelah mendapatkan hasil dari pengabdian, lalu tim membuat laporan pertanggungjawaban kepada pimpinan sebagai wujud tanggung jawab.

\section{HASIL DAN PEMBAHASAN}

Pengabdian kepada masyarakat didahului dengan persiapan pelaksanaan kegiatan. Kegiatan pengabdian bertujuan untuk memberikan informasi tentang jadwal kegiatan dan tujuan pelaksanaan kegiatan, serta mencari kesepakatan terhadap jadwal pelaksanaan dan materi yang akan digunakan. Dalam pengabdian ini diikuti oleh sepuluh anak-anak sekolah dasar. Kegiatan dilaksanakan pada Kamis, Jumat, dan Sabtu, yaitu tanggal 1921 April 2019. Kegiatan pengabdian ini terbagi tiga bagian, yaitu hari pertama tim melakukan pendataan, memberikan penjelasan, dan menugasi anak-anak untuk menggambar. Hari kedua, tim meminta anak-anak mengambar lalu menceritakan gambar yang dibuatnya. Hari ketiga, tim menugasi kembali pada anak-anak untuk menggambar lalu menceritakan kembali gambar tersebut dengan menggunakan bahasa yang baik. Kemudian tim, membuat penilaian yang kedua untuk melihat perkembangan kemampuan anak-anak dalam bercerita. Menurut Sudjana (2014: 8) tingkat keberhasilan dapat dilihat dari kenaikan nilai rata-rata atau kenaikan persentasenya, yaitu $75 \%$.

\section{Tahap Awal}

1. Anak-anak diberikan pandangan terlebih dahulu mengenai perkembangan intenet yang semakin pesat.

2. Anak-anak diberikan gambaran bagaimana pengaruh penggunaan internetterutama untuk berkomunikasi dengan lingkungan.

3. Penyuluh memberikan materi berbicara dan media gambar.

4. Penyuluh meminta anak untuk menggambar.

5. Setelah menggambar, anak tersebut dapat menceritakan tentang apa yang ia gambar.

Partisipasi anak dalam kegiatan

1. Anak Menyiapkan buku gambar, alat tulis dan mengambar.

2. Anak mulai menggambar sesuai imajinasi masing-masing.

3. Anak mulai mewarnai gambar.

4. Setelah menggambar, menceritakan isi gambar mereka. 


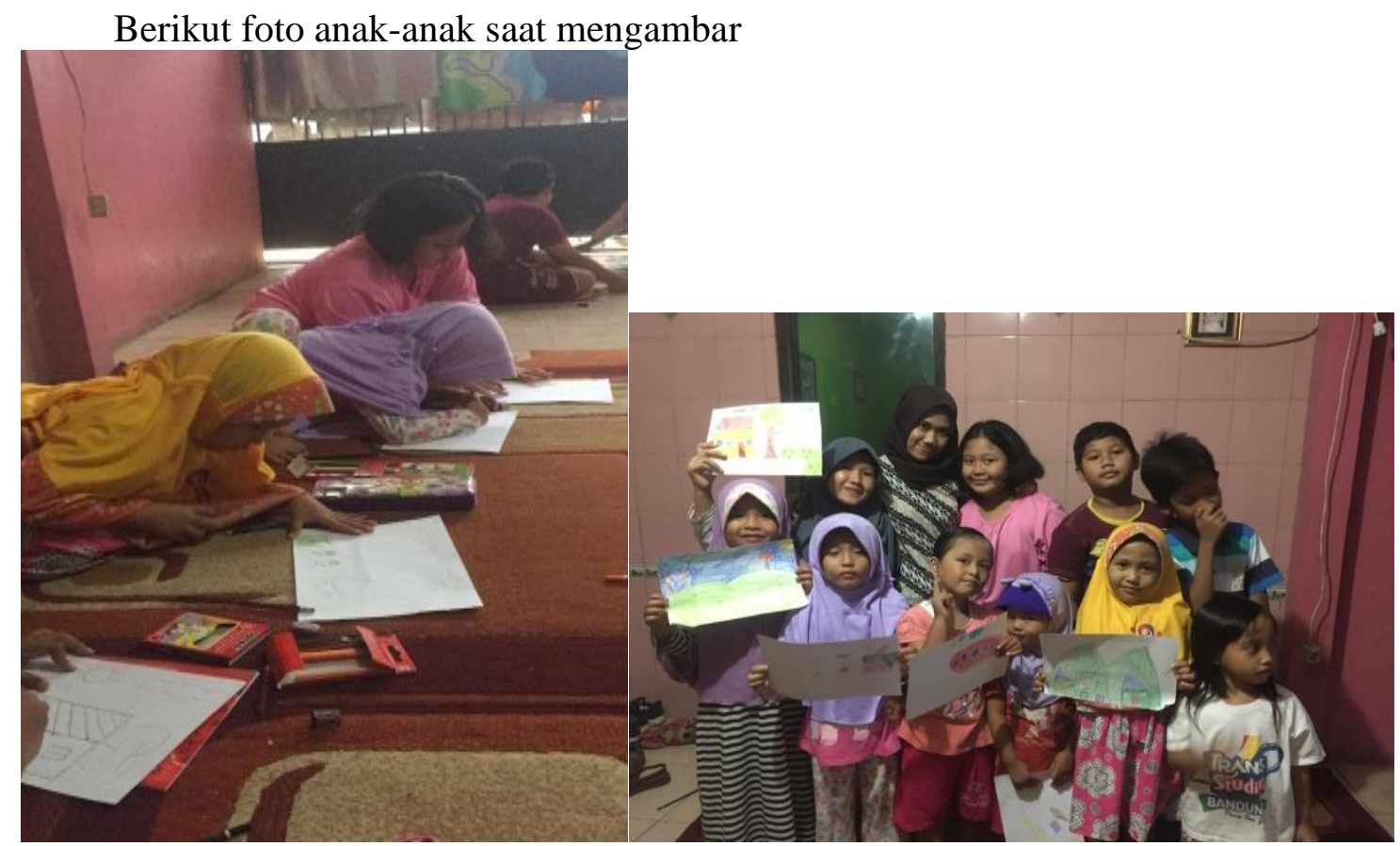

Berikut data yang disajikan dalam tabel

\begin{tabular}{llcccc}
\hline No & Nama & \multicolumn{2}{c}{ Nilai } & \\
& Anak & & & & Siklus II \\
& & Siklus I & Mengambar & Bercerita \\
\cline { 3 - 6 } & & Mengambar & Bercerita & 75 & 80 \\
$\mathbf{1}$ & Sofia & 70 & 75 & 78 & 80 \\
$\mathbf{2}$ & Tyas & 75 & 75 & 75 & 75 \\
$\mathbf{3}$ & Nesya & 70 & 70 & 75 & 73 \\
$\mathbf{4}$ & Mesya & 70 & 72 & 73 & 75 \\
$\mathbf{5}$ & Sinta & 70 & 74 & 75 & 80 \\
$\mathbf{6}$ & Putri & 70 & 70 & 75 & 80 \\
$\mathbf{7}$ & Tiara & 70 & 76 & 75 & 75 \\
$\mathbf{8}$ & Syifa & 70 & 73 & 72 & 75 \\
$\mathbf{9}$ & Maulana & 65 & 70 & 73 & 770 \\
$\mathbf{1 0}$ & Fatan & 70 & 70 & 746 & \\
& Jumlah & 700 & 725 & & 75 \\
\end{tabular}

Berdasarkan nilai pada tabel di atas, bahwa nilai mengambar pada siklus I dari sepuluh anak, yaitu 700 atau $70 \%$, sedangkan nilai bercerita 725 atau 72,5\%. Lalu siklus II nilai yang didapat oleh anak-anak, yaitu nilai mengambar 746 atau $75 \%$, sedangkan nilai bercerita menjadi 770 atau $77 \%$. Jadi, media gambar dapat meningkatkan kemampuan bercerita. Nilai menggambar pada siklus I ke siklus II mengalami peningkatan sebesar 46 point, sedangkan nilai bercerita juga mengalami peningkatan, yaitu 45 point. 
Tahap Akhir adalah evaluasi proses kegiatan yang telah dilaksanakan. Evaluasi proses meliputi keaktifan peserta, kehadiran dan hasil yang dicapai.

\section{SIMPULAN}

Setelah dilakukan pengabdian kepada masyarakat, dapat simpulkan, bahwa untuk meningkatkan kemampuan bercerita bisa memakai media gambar. Hal ini dapat dilihat dari 1) penggunaan metode bercerita efektif untuk meningkatkan perbendaharaan kosakata, 2) media gambar dapat mendukung dalam kegiatan belajar mengajar, 3) media gambar dapat membangun ide-ide, inspirasi, kreativitas, dan 4) media gambar juga dapat dijadikan media seni dalam berkarya.

Saran dari hasil pengabdian pada masyarakat, yaitu

1. Hendaknya dalam memulai proses belajar hal pertama yang dilakukan, yaitu memotivasi dan menenangkan anak agar suasana kondusif.

2. Dalam kegiatan belajar diusahakan menggunakan variasi kegiatan pembelajaran, hal ini untuk mencegah anak bosan.

3. Hasil PKM ini dapat menjadi acuan kegiatan dalam meningkatkan kemampuan bercerita.

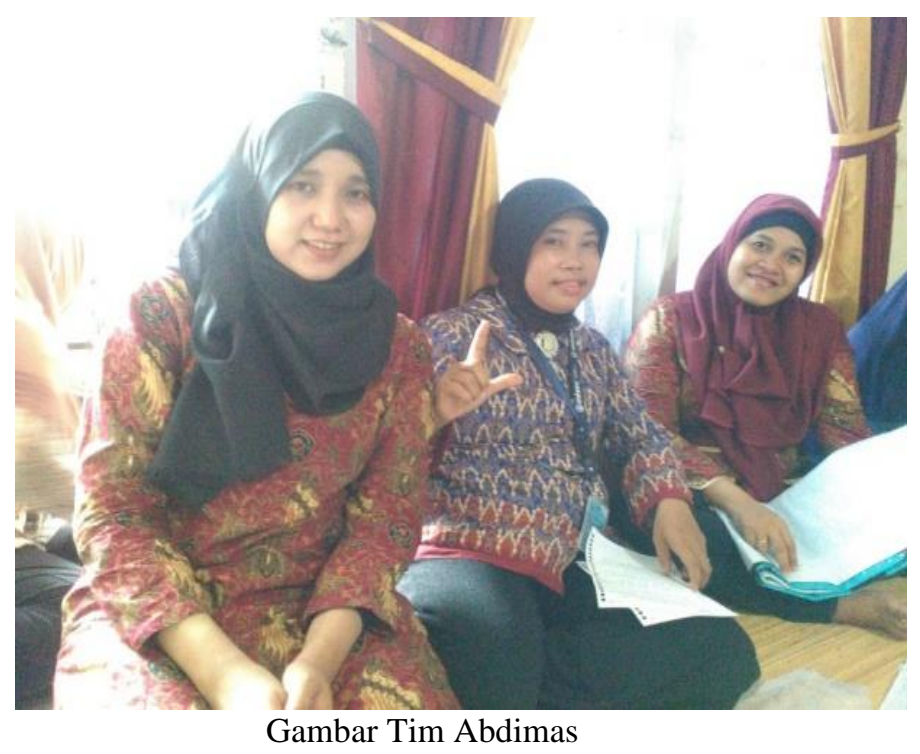

\section{DAFTAR PUSTAKA}

Anita , S. (2008). Media Pembelajaran. Surakarta: LPP UNS Press.

Arsyad, A. (2011). Media Pembelajaran. Jakarta: PT Raja Grafindo Persada.

Departemen Pendidikan Nasional. (2000). Permainan Membaca Dan Membaca Di Taman Kanak-kanak. Jakarta: DEPDIKNAS

Marlina, E., Apriliya, S., \& Hamdu, G. (2018). Kemampuan Bercerita Siswa SD Menggunakan Buku Pop Up. PEDADIDAKTIKA: Jurnal Ilmiah Pendidikan Guru Sekolah Dasar, 5(1), 84-99. Retrieved from http://ejournal.upi.edu/index.php/pedadidaktika/article/view/7214 
Musfiroh, T. (2005). Bercerita Untuk Anak Usia Dini. Jakarta: Depdiknas

Sadiman, A.S. (2008). Media Pembelajaran. Seri Pustaka Teknologi Pendidikan Nomor 6. Jakarta: Raja Grafindo Persada.

Suyanto, E. (2011). Membina, Memelihara, dan Menggunakan Bahasa Indonesia Secara Baik dan Benar. Yogyakarta: Ardana Media.

Sudjana, N. (2014). Penilaian Hasil Belajar Proses Belajar Mengajar. Bandung: PT Rosda Karya.

Subana dan Sunanti. (2011). Strategi Belajar Mengajar Bahasa Indonesia: sebagai Pendekatan, Metode, Teknik, dan Media Pengajaran. Bandung: Pustakan Setia.

Sudjana, N. dan Rivai, A. (2009). Media Pembelajaran (Penggunaan dan Pembuatannya). Bandung: Sinar Baru Algensindo. 